\title{
Microfacies, Sedimentary Environment and Sequence Stratigraphy of the Asmari Formation in Masjed-I-Soleyman Oil Field, Khuzestan Provence, Southwest Iran
}

\author{
Mohamad Lorestani $^{1}$, Abdolhosein Kangazian ${ }^{2 *}$, Amrolah Safari ${ }^{3}$, Mohamad Reza Noura1, \\ Ehsanolah Nasehi \\ ${ }^{1}$ Department of Geology, Faculty of Sciences, Islamic Azad University, Zahedan Branch, Zahedan, Iran \\ ${ }^{2}$ Department of Geology, Faculty of Sciences, Islamic Azad University, Esfahan (Khorasgan) Branch, Esfahan, Iran \\ ${ }^{3}$ Department of Geology, Faculty of Sciences, Esfahan University, Esfahan, Iran \\ Email: "kangazian@khuisf.ac.ir
}

Received 10 February 2016; accepted 15 August 2016; published 18 August 2016

Copyright (C) 2016 by authors and Scientific Research Publishing Inc.

This work is licensed under the Creative Commons Attribution International License (CC BY).

http://creativecommons.org/licenses/by/4.0/

(c) (i) Open Access

\begin{abstract}
The Oligo-Miocen Asmari Formation is the most important oil reservoir in Iran. This study deals with facies associations, sedimentary environments and sequence stratigraphy of this formation in Masjed-I-Solyman oil field by using petrographical studies and statistical analysis. These findings show that studied succession belongs to the upper Asmari Formation (Bordigalian) with nine microfacies assosiations that consist of four wackestone, four packstone and one Boundstone microfacies. These microfacies were deposited in the inner and middle parts of a homoclinal carbonate ramp. Sequence stratigraphy studies express that the succession could be discriminated to four third order sedimentary sequences that would have been deposited under global sea level fluctuation (Eustasy).
\end{abstract}

\section{Keywords}

Oligo-Miocen, Sedimentary Environment, Asmari Formation, Masjed-I-Soleyman Oil Field, Sequence Stratigraphy

\section{Introduction}

The Asmari Formation hosts one of the prolific oil reservoirs in the world [1]. It is present in most of the Zagros ${ }^{*}$ Corresponding author.

How to cite this paper: Lorestani, M., Kangazian, A., Safari, A., Noura, M.R. and Nasehi, E. (2016) Microfacies, Sedimentary Environment and Sequence Stratigraphy of the Asmari Formation in Masjed-I-Soleyman Oil Field, Khuzestan Provence, Southwest Iran. Open Journal of Geology, 6, 840-851. http://dx.doi.org/10.4236/ojg.2016.68064 
basin in the southwest of Iran. The Zagros Mountains of Iran are divided into the three principal tectonic units included the Zagros fold-thrust zone, the imbricated zone and the Urumieh-Dokhtar magmatic zone [2]. The type section of the Asmari Formation, measured in the Tang-e-Gele Torsh outcrop in Khuzestan province by Richardson in 1924, consists of 314 m of limestones, dolomitic limestones, and argillaceous limestones [3]. Generally, the Asmari Formation conformably overlies the deeper microfacies of the Palaeocene-Oligocene Pabdeh Formation. The Gachsaran Formation unconformably overlies the Asmari Formation in most places. Based on the Biostratigraphy and Strontium isotope studies, Asmari Formation was deposited from Ruplian to Burdigalian ([4] [5]). Most of previous studies on this formation are related to biostratigraphy (e.g. [6] [7]), microfacies and sedimentary environment (e.g. [8] [9]) and sequence stratighraphy (e.g. [4] [5] [9] [10]).

This formation is widespread, with very varied characteristics of lithostratigraphy, biozones and microfacies in different locations in the Zagros Basin [3]. Most researches of the Asmari Formation involve outcrop sections. Studies of the subsurface sedimentary successions of the Asmari Formation are necessary for exploration of the oil reservoirs. Also, the Masjed-I-Soleyman (MIS) oil field is one of the oldest oil fields in Iran, and it needs comprehensive research about microfacies analyses and palaeoenvironment reconstruction.

This study ,deals with sedimentology and sequence stratigraphy of the Asmari Formation in Masjed-I-Soleyman (MIS) oil field, has three objects: 1) the description of fasies association and their distribution along the succession, 2) the reconstruction of carbonate paleoenvironment, and, 3) the recognition of third order sequences of the Formation in this field.

\section{Geographical and Geological Setting of the MIS Oilfield}

MIS oil field is located in 135 kilometer of the north of Ahwaz city and in the north of the Dezful Embayment. MIS anticline is a concentricity asymmetrical fold with 30 kilometer length and 7 kilometer width. In the north and south of the MIS oilfield, two large thrust faults caused upward displacement of this area relative to nearby fields (like: Karun, Paresiah and Naft-e-Safid oil fields). Because of its spatial situation, this field has complicated geological position (Figure 1).

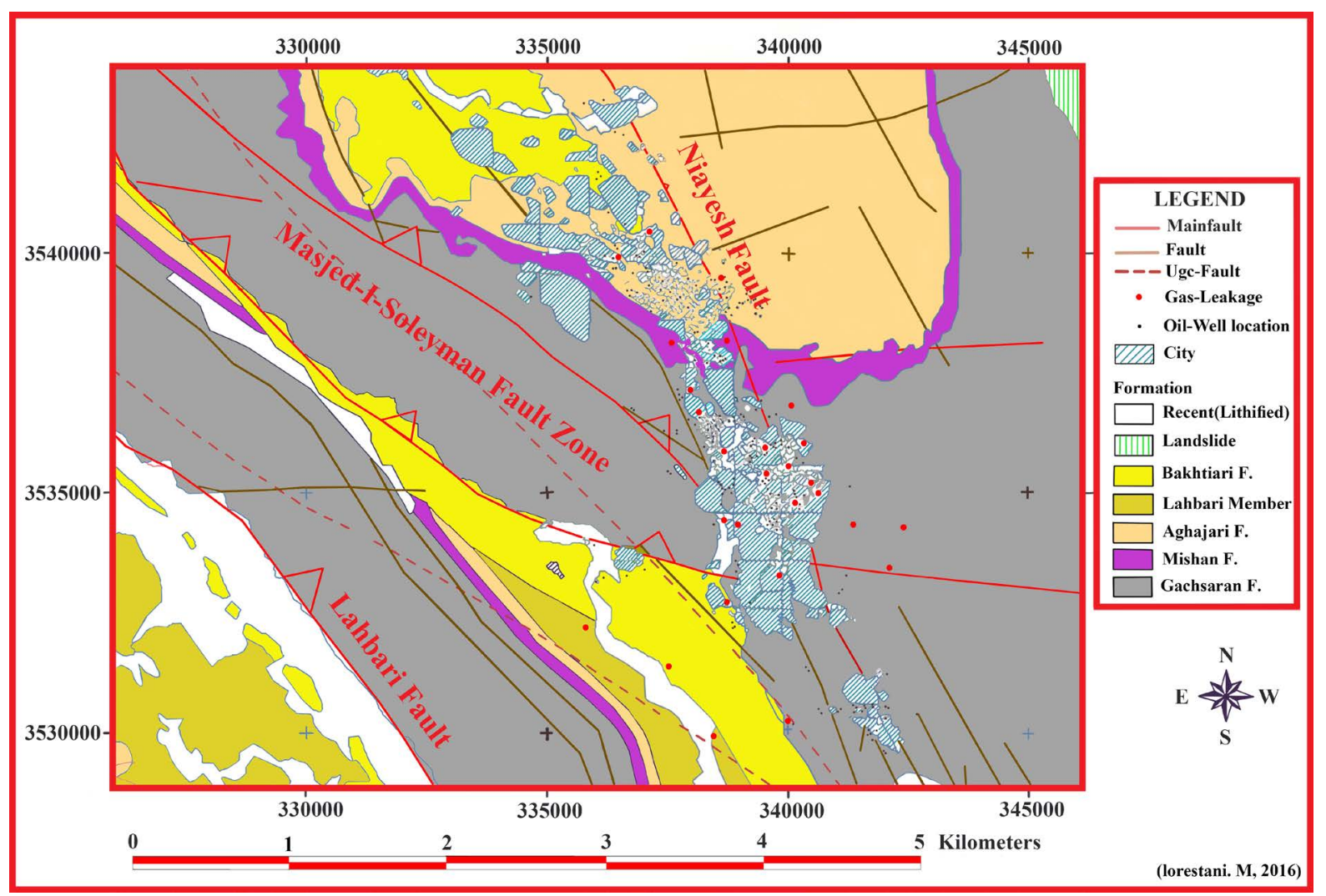

Figure 1. Geological map of Masjed-I-Soleyman oil field, Dezful Embyment, (after Mahouri [11]). 
MIS reservoir is initial oil reservoir that explored in 1908 with drilling No. 1 well (M1) (Figure 2). This oil reservoir only with 360 meter depth has nonresistant Cap rock with many fractures. Motiei [3] believed that Tectonic conditions in MIS Anticline cussed thinning of the Gachsaran Formation as main cap rock of the Asmari reservoir. Therefore the quality of the cap rocks on the crest line of the anticline on top of Asmari reservoir is very weak.

\section{Methodology}

One hundred and ninety one samples were collected from cores of well no. 186 in MIS oil field to represent the entire thickness of the Asmari Formation and thin sections were prepared, which were etched and stained for calcite and dolomite as matrix. In this investigation, characteristics of Carbonate thin sections were studied based on Flügel ([12] [13]) and Scholle \& Olmer-Scholle [14] and were classified according to Danham's [15] and Folk's methods [16]. Facies characteristics were described in thin sections, according to the schemes proposed by Wright [17], and contrasted with the microfacies proposed by Flügel [13] and Wilson [18]. Walter's law and facies relationships were calculated based on the proposed methods by Selly [19]. Methods and terminology which were planned by Catuneanu [20] and Catuneanu et al. [21] were used for description and analyze of the sequence stratigraphy. Biozonation and age determinations are based on strontium isotope stratigraphy recently established for the Asmari Formation by Van Buchem et al. [5].

\section{Results}

\subsection{Lithostratigraphy}

Study of cores obtain from Succession of Asmari Formation shows that this Succession mainly is formed from Limestone (Figure 3(a)), Dolomitic limestone (Figure 3(b)), Lime Dolostone (Figure 3(c)), Dolostone (Figure 3(d)), Sandy Limestone (Figure 3(e)), Sandy Dolostone (Figure 3(f)), and occasionally Anhydrite. This Lithology composition significantly is the same as the upper Asmari member [3].

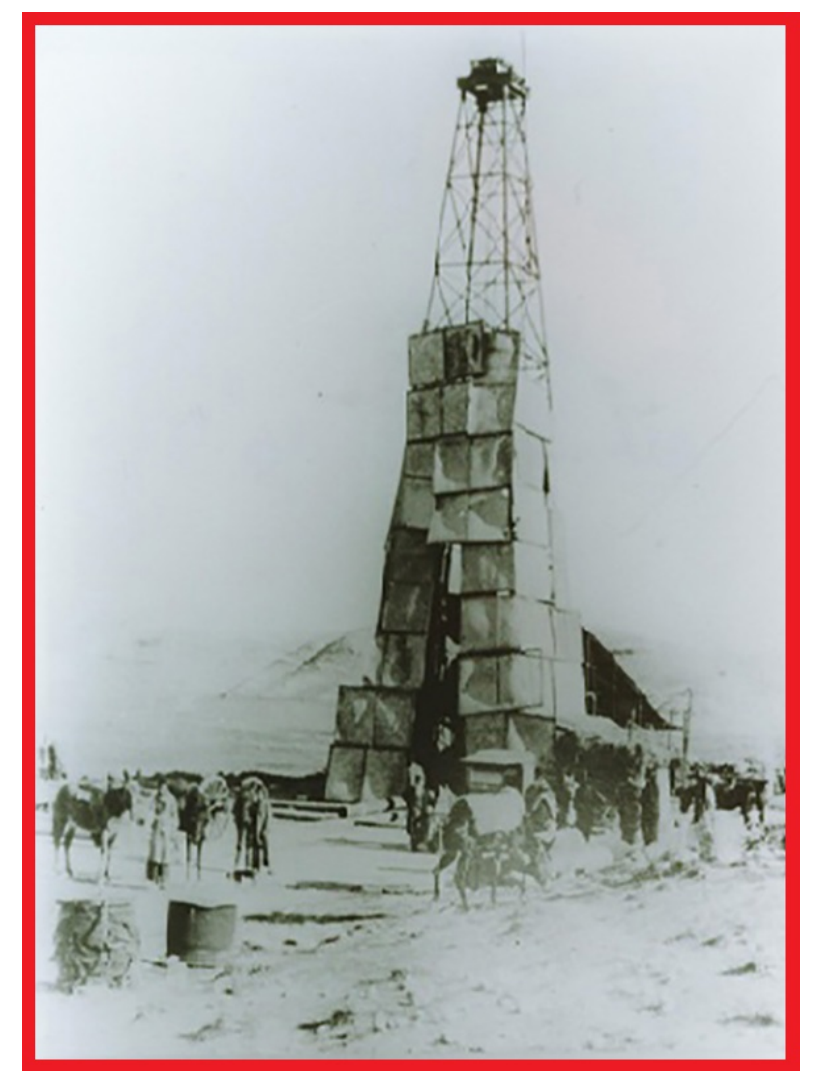

Figure 2. First oil well of Masjed-I-Soleyman oilfield that was drilled in 1908 (unpublished picture from National Iranian south oil-company). 


\subsection{Biostratigraphy}

Only one assemblage of foraminifera recognized in the studied area and was discussed as follows:

The most important foraminifera in this assemblage are: Borelis melo curdica, Dendritina rangi, Operculina complanata, Peneroplis evolutus, Meandropsina anahensis, Peneroplis thomasi, Triloculina trigonula, Austrotrillina asmariensis, Borelis cf. pygmaea, Miogypsinoides sp., Elphidium sp., Valvulina sp., Archaias sp., Quinqueloculina sp., Schlumbergerina sp., Bigenerina sp., Pyrgo sp., Nummulites sp., Spiroclypeus sp., Discorbis sp., Textularia sp., Rotalia sp. This assemblage is correlated with Borelis melo curdica-B. melo melo Assemblage zone (Zone No. 7) of Van Buchem et al. [5] and Laursen et. al. [22] and is attributed to the Burdigalian age (Table 1).

The most important nonforaminifera in this succession consist of: Lithothaminium sp.,Lithophyllum sp., coral, Echinodermata, Bryozoa, Tubucelaria sp., Gastropoda, Ostracoda (Figure 10).

\subsection{Microfasies Analysis}

Microscopic analysis of the Asmari Formation in the study oilfield resulted in the definition of 9 microfacies types. According to their environmental interpretation and to their vertical transitions, recognized microfacies were subdivided into 5 basic types of facies associations: 1) Lagoon facies association (L), 2) Bar facies associations (B), 3) Restricted marine facies associations (R), 4) Open marine facies associations (O), and, 5) Mid ramp facies associations $(\mathrm{M})$. The general description and interpretation of the facies associations are discussed from shallow to deep in the following paragraphs.
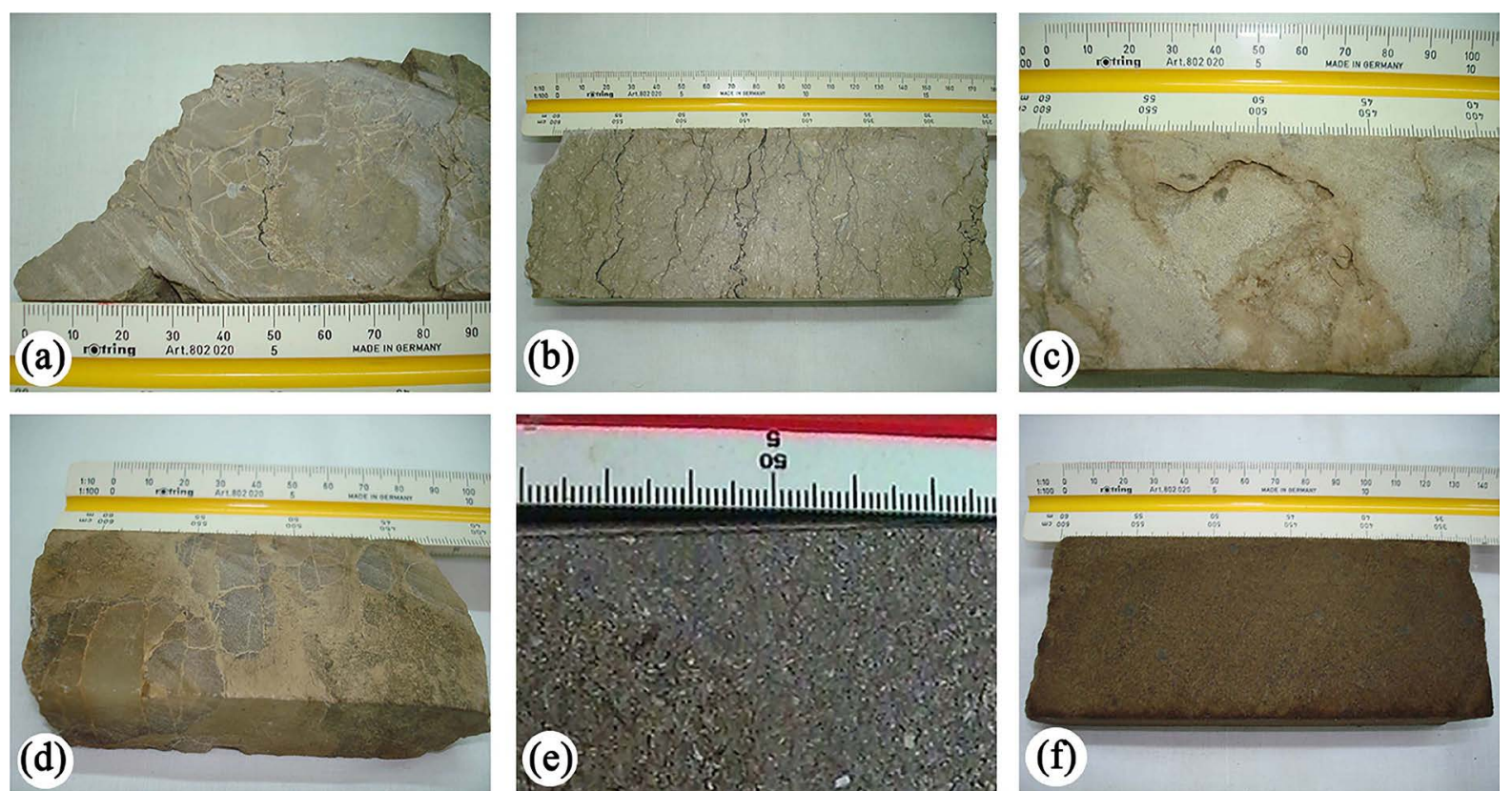

Figure 3. Core samples of the Asmari Formation, Well\#No186, MIS oilfield, eastern south of Iran. (For detail see text).

Table 1. Biozonation presented by Laursen et al. [22] and Van Buchem et al. [5]). (After Vaziri-Moghaddam et al. [23]).

\begin{tabular}{ccc}
\hline Stage & No. & Assemblage zone ([5] [22]) \\
Burdigalian & 7 & Borelis melo Curdica-B. melo melo \\
Aquitanian & 6 & Indeterminate zone \\
Aquitanian & 5 & Miogypsina-Elphidium sp. 14-Peneroplis farsensis \\
Chattian & 4 & Archaias asmaricus-A. hensoni-Miogypsinoides complanatus \\
Rupelian-Chattian & 3 & Lepidocyclina-Operculina-Ditrupa \\
Rupelian & 2 & Nummulites vascuse-N. fichteli \\
Eocene-Oligocene & 1 & Globigerina spp.-Turborotalia cerroazulensis-Hantkenina
\end{tabular}




\subsubsection{Lagoon Facies Associations (L)}

This facies association only consistes of Bioclastic pelloidal Packstone Microfacies (L1). Identifiable components of this microfacie include Red Algea fragments, Rotalia (and some other foraminifers like Miliolid, Borelis, Miogipsinoides), Mollusc and Echinoid fragments (Figure 4). This microfacies is as the same as SMF16 [18]. The texture of this facies indicate moderate energy shallow waters.

The occurrence of large number of porcellaneous imperforate foraminiferal tests may point to the depositional environment being slightly hypersaline. Wilson [18] referred the same microfacies to restricted marine sub-environment.

\subsubsection{Bar Facies Association (B)}

1 microfacies type involves red algal coral Boundstone (B1). This microfacies consists of red algal fragments (e.g. Lithophyllum and Lithothaminium sp., Subtraniphyllum), coral bimorphs, and, sometime, micrite matrix. Some echinoid and bryozoan fragments can be seen in the microfacies (Figure 5).

According to Flügel [13] and Tucker and Wright [24], corallinacean and coral reefs are interpreted as open marine facies of an inner ramp with free marine water-circulation, above the fire-weather wave base. This interpretation is supported by patchy form of the facies. The microfacies is comparable with RMF12 [13].

\subsubsection{Restricted Marin Facies Association (R)}

Typically, this facies association includes sandy, imperforate foraminifera wackestone (R1) and bioclast, imperforate foraminifera packstone (R2). Skeletal grains consist of diverse imperforate foraminifera such as miliolids, Archaias, Peneroplis, and Dendritina rangi). Additional components are echinoderm, Mollusca, Bryozoa, Gastropoda, and corallinacean fragments. Lime mud occupies the pores of these mud to grain-supported textures (Figure 6). Occasionally, bioturbation can be observed in these microfacies. RMF 16 [13] is proposed for equivalent of these microfacies.

Occurrence of platform-interior (imperforate foraminifera) components indicates that sedimentation took place in a semi restricted, low (R1) to moderate (R2) energy environment ([13] [18] [25]). Porcellaneous foraminifer indicate that the sedimentary environment was situated in the euphotic zone [26].

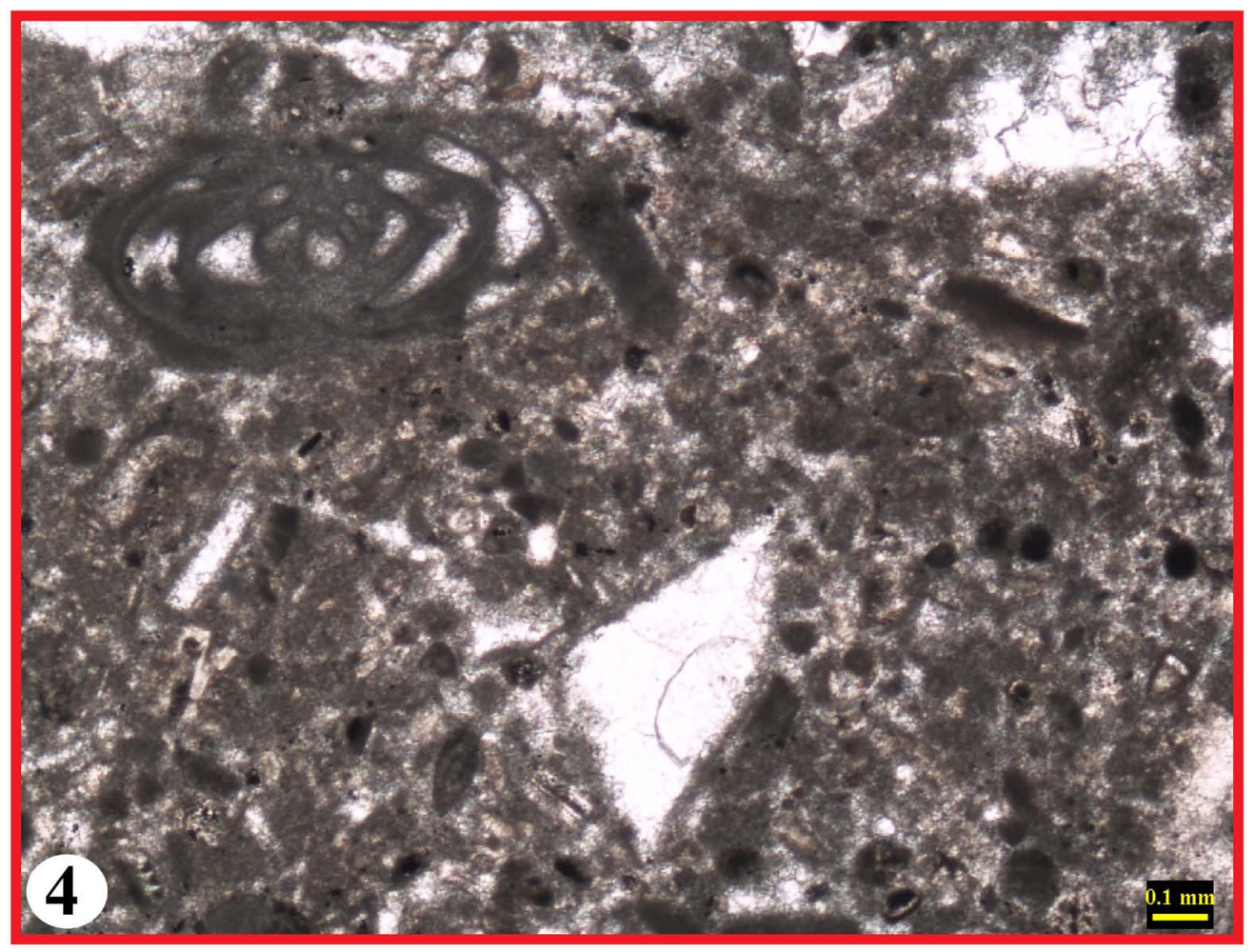

Figure 4. Bioclastic pelloidal Packstone (L1). 


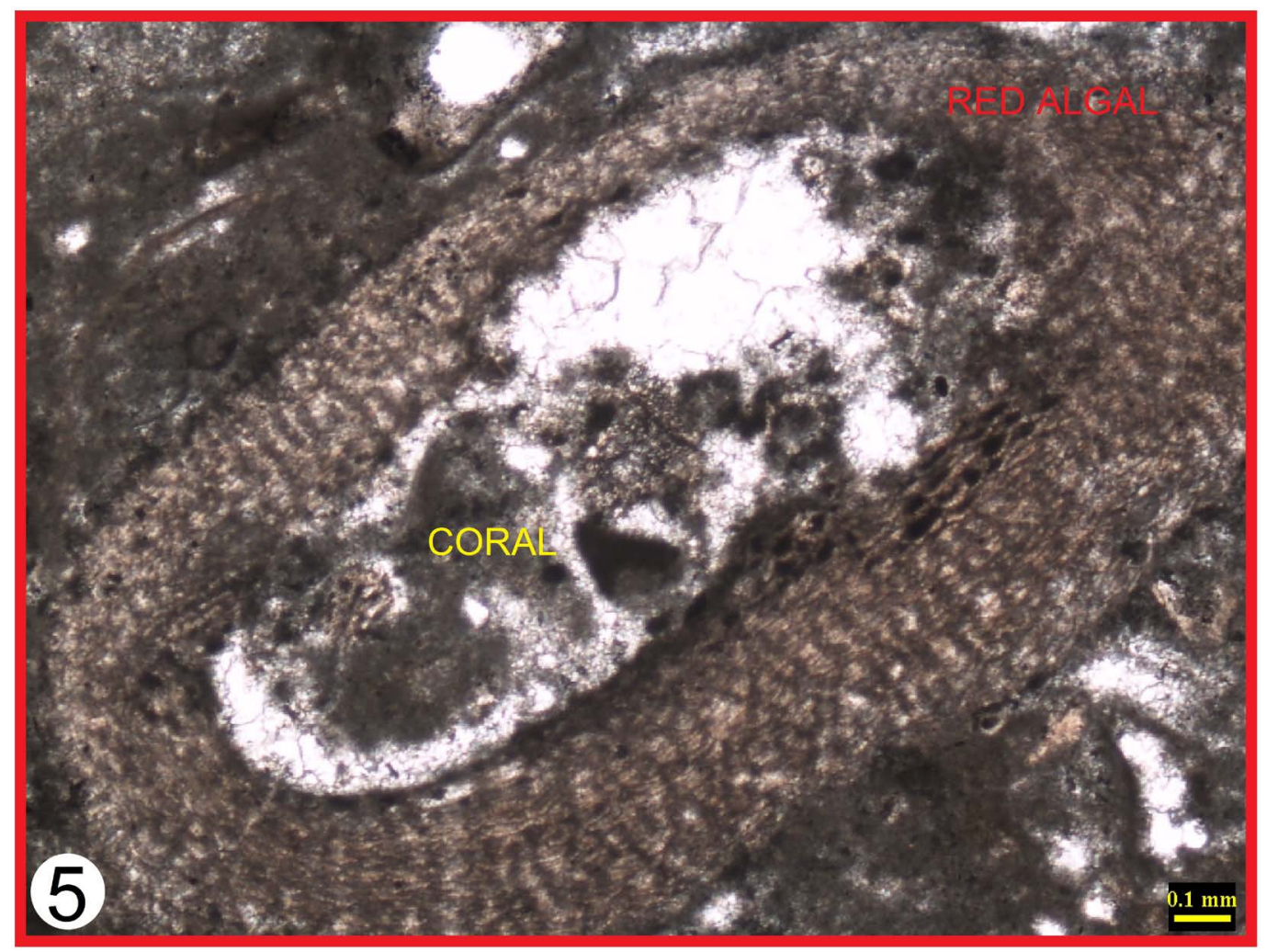

Figure 5. Red algal coral Boundstone (B1).

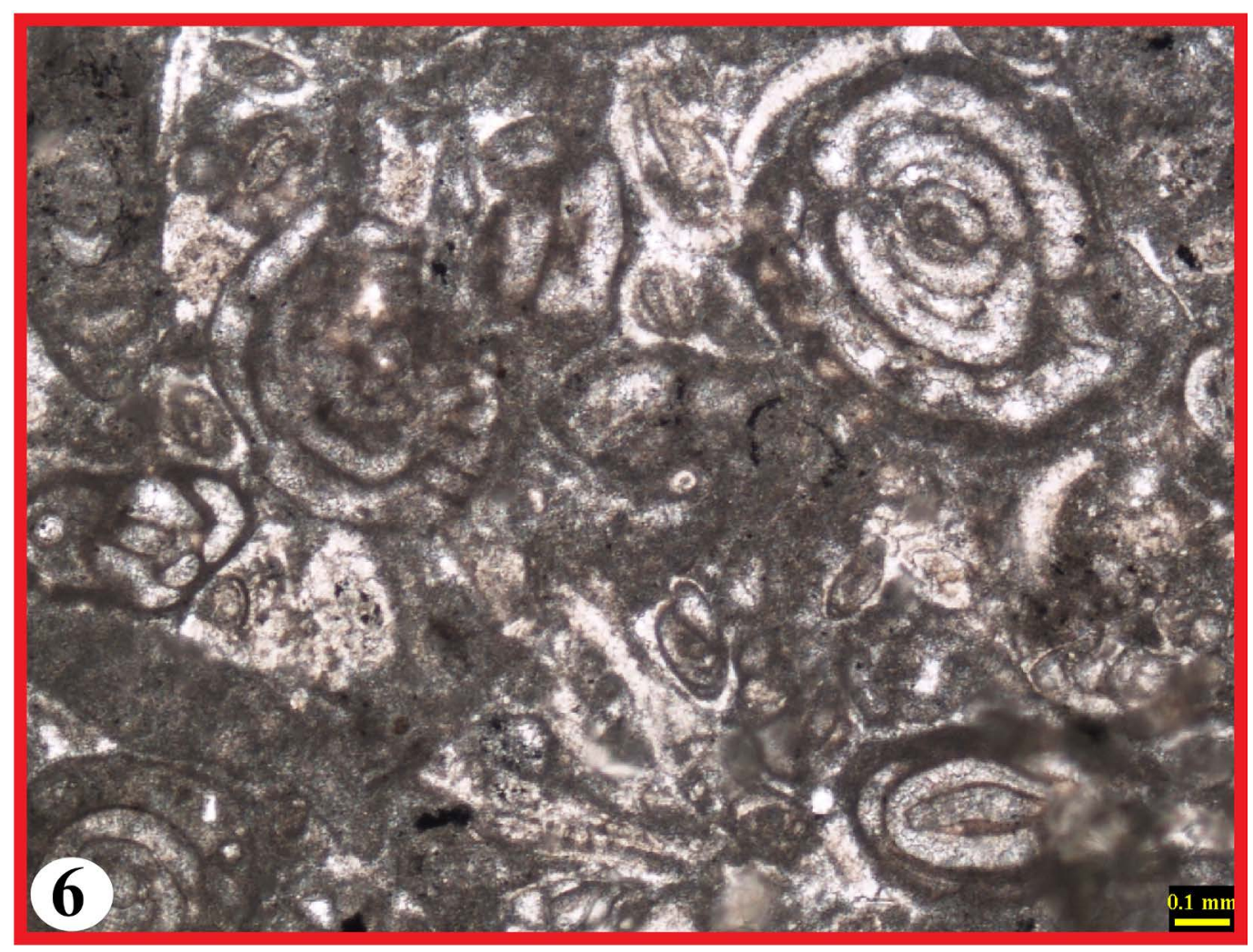

Figure 6. Bioclast, imperforate foraminifera packstone. 


\subsubsection{Open Marine Facies Association (0)}

Typically this facies association includes echinoid wackestone (O1), echinoid packstone (O2), red algae wackestone (O3), and, red algea packstone (O4). The main characteristic of microfacies $\mathrm{O} 1$ and $\mathrm{O} 2$ is abundant segments of echinoderm and benthic foraminifers (Rotalia). Whereas Identifiable components of microfacies O3 and $\mathrm{O} 4$ include Corallinacea fragments. Occasionally, sandy quartz grains increased and a sandy allochemical limestones (Mont 1985) occurred. Microfacies O1 and O2 (Figure 7(a) \& Figure 7(b)) are comparable with RMF7 [13] and microfacies O3 and O4 (Figure 7(c) \& Figure 7(d)) are equivalences of RMF15 [13].

This facies association is characterized by features pointing to low and moderate (sometimes high-energy) background conditions (matrix to grain-supported fabrics) and by presence of poorly or moderately diverse oligotrophic (rarely mesotrophic) patch-reef fragments, macro benthic assemblages like echinoderms, corallinacean sand-size and foraminifera test.

\subsubsection{Mid ramp Facies Association (M)}

This facies association only includes bioclastic pelloidal wackstone (M1). This microfacies consists of pelloide, red algea and echinoderm fragments, pelagic and benthic foraminifera tests (Figure 8). Bioturbation can be seen in this microfacies. Occasionally, sandy quartz grains increased and a sandy allochemical limestones [27] occurred. RMF3 [13] is proposed for equivalent of this microfacies. Pelagic foraminifera and matrix-supported fabric indicate that this microfacies occurred in low-energy shallow marine environment situation, bellow fairweather wave base.

\section{Discussion and Conclusion}

\subsection{Sedimentary Model}

Microfacies and Facies associations analyses have permitted the differentiation of several carbonate marine sys-

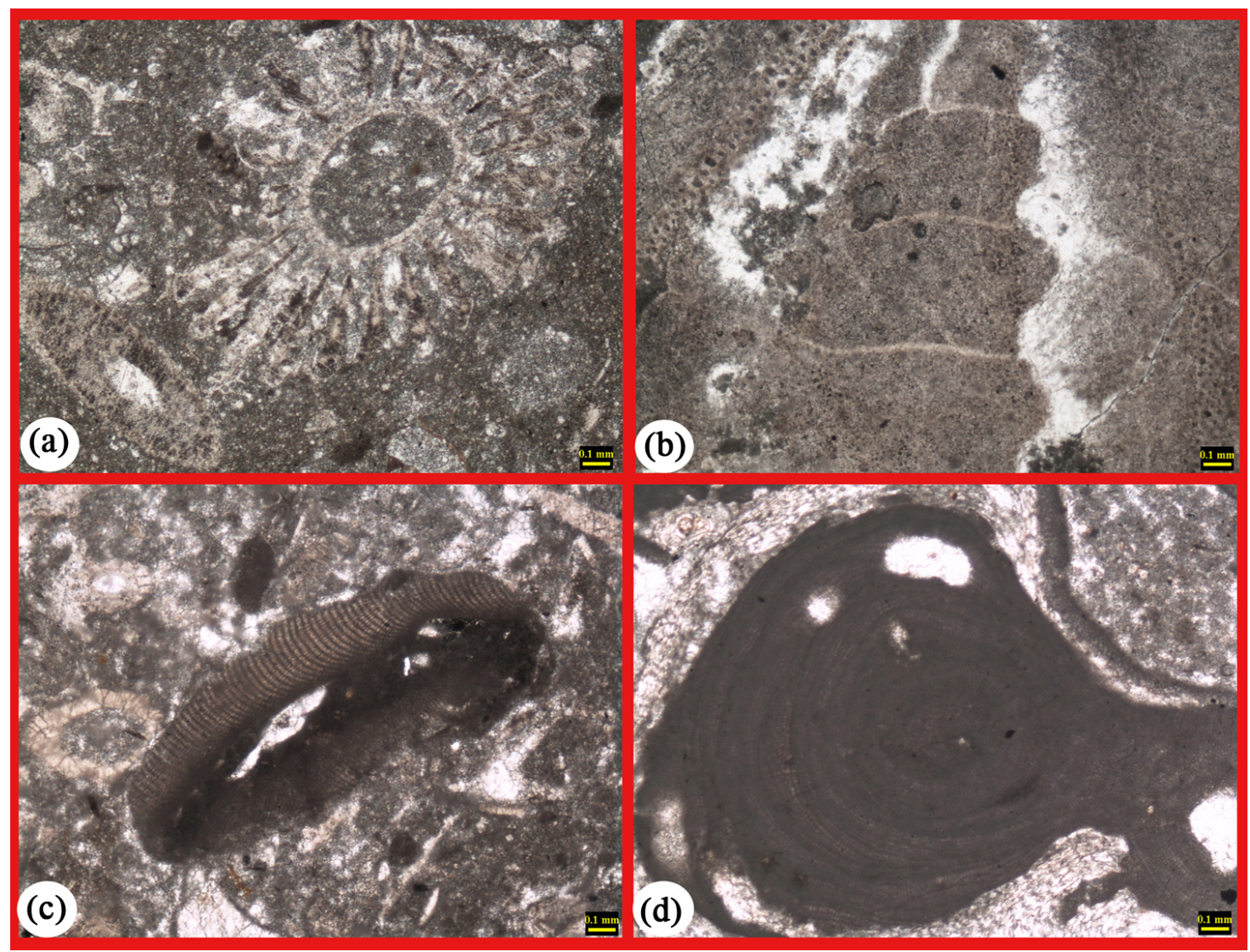

Figure 7. Open marine Microfacies (O). (See the text). 


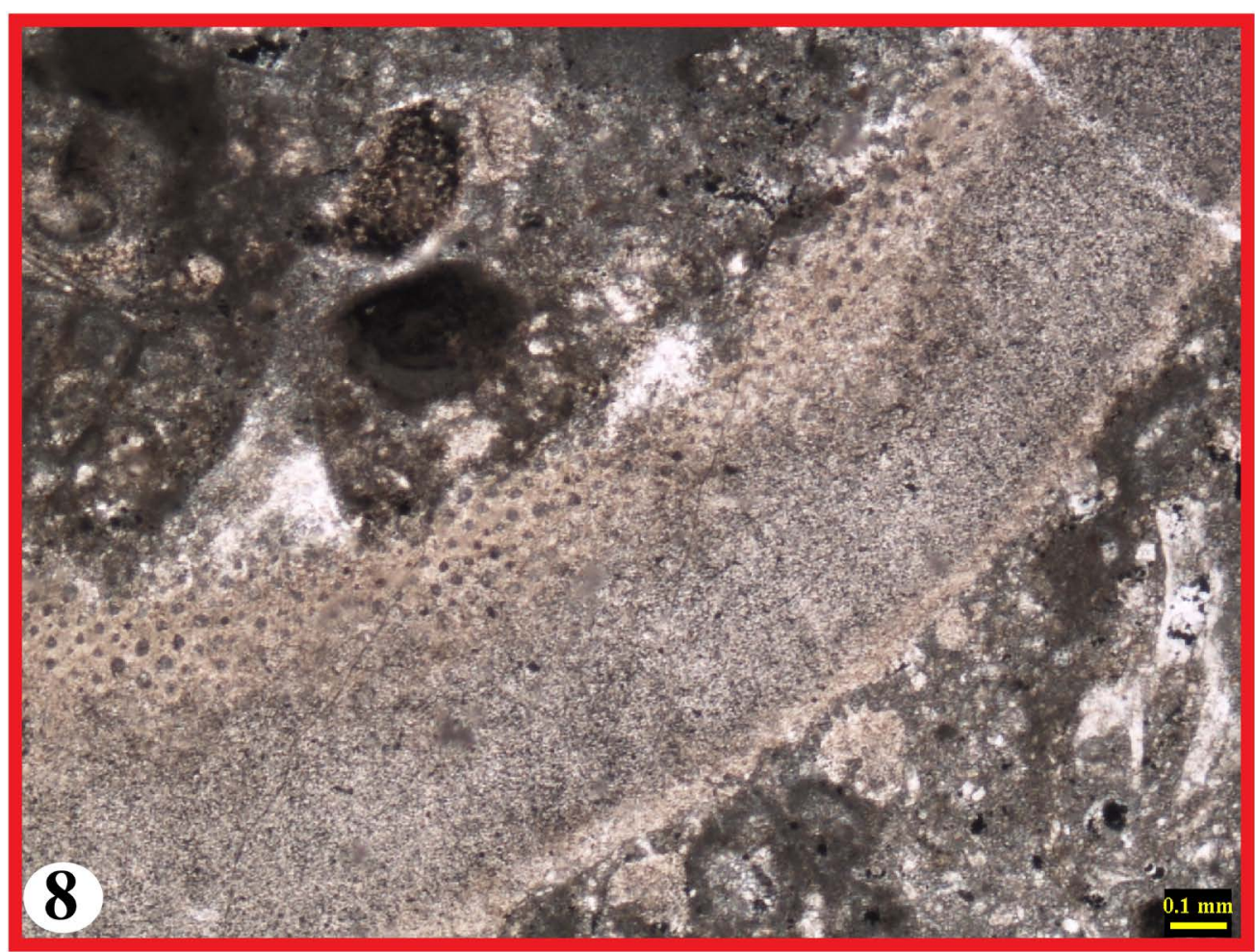

Figure 8. Bioclastic pelloidal wackstone (M1).

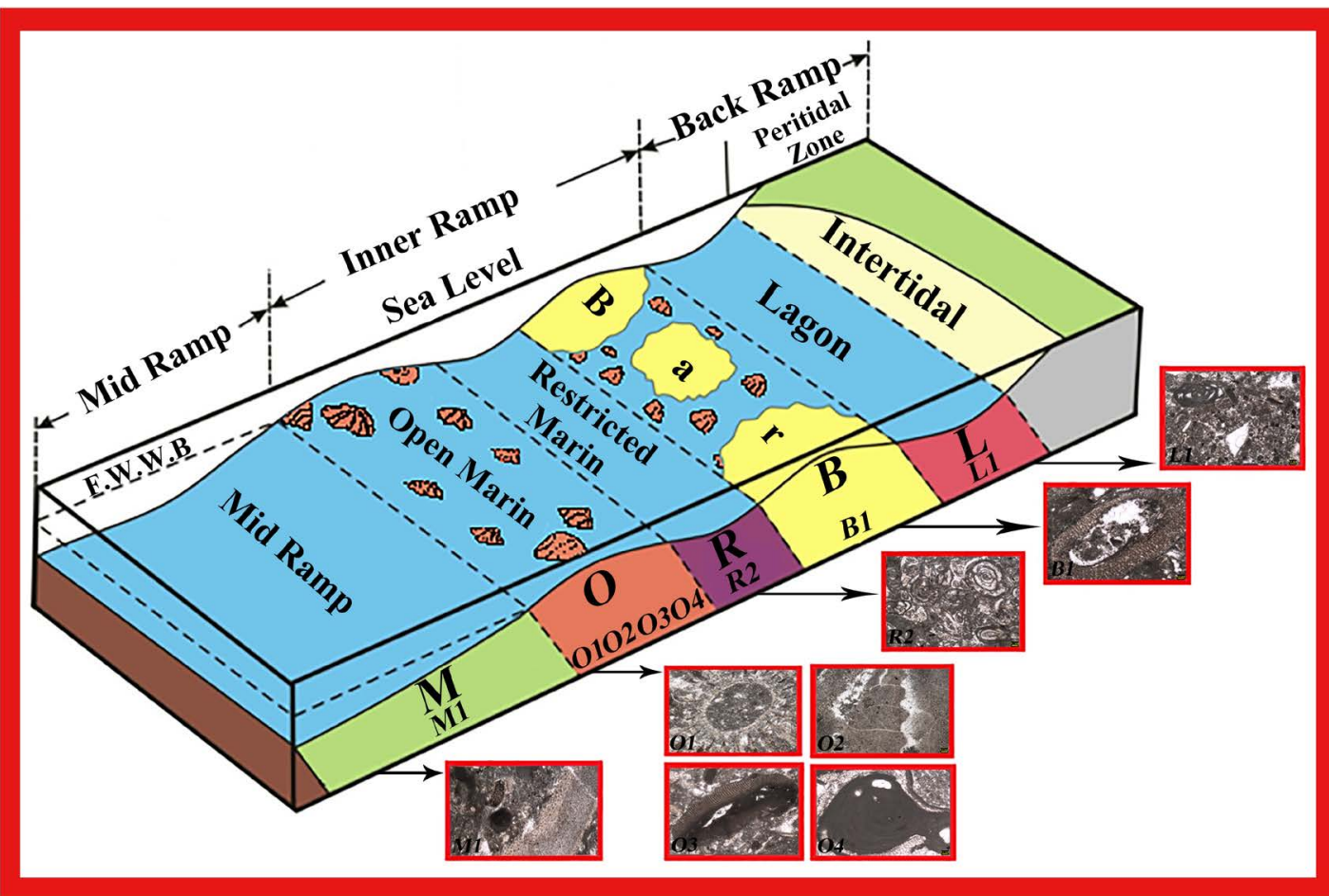

Figure 9. Depositional model for the platform carbonates of the Asmari Formation at MIS oilfield.

tem environments including mid ramp, open marine, semi restricted marine, shoal, and lagoon (Figure 9). These 5 depositional environments of the Burdigalian in the study oilfield are similar to those found in many modern 
carbonate depositional settings. By comparing the microfacies criteria with those of modern carbonate depositional settings, such as the Persian Gulf, and prominent carbonate classical facies models, like Flügel's model [13], a very low gradient homoclinal carbonate ramp model is suggested for the Asmari Formation in the MIS oilfield (Figure 9). Lack of barrier reef and turbidite microfacies support this suggestion. It seems that the Asmari Formation depositional environment was similar to the modern homoclinal carbonate ramp of the Persian Gulf. Microfacies relationships (based on the results of the selly's method [19]), their situations in the succession, and, also, locations of their comparable RMFs in the Flügel's facies model [13] show that all the microfacies, except M1, have deposited in inner portion of the ramp (Figure 9).

\subsection{Sequence Stratigraphy}

The studied succession can be framed in a sequence stratigraphic context. As a guide, we used the principal sequence stratigraphic concepts developed by many workers (e.g. [20] [21]) to recognize TST (transgressive systems tract), mfs (maximum flooding surface), HST (Highstand systems tract) and sequence boundaries.

Based on the detailed sedimentology and stratigraphy study, on the parasequences and parasequence sets trends, on the vertically changes of the environments (Shallowing diagram) along the succession, we defined one incomplete and three complete third-order depositional sequences (Table 2, Figure 10).

Separating with SBII, all these sequences can be called type two sequences. Except first sequence (Sq1), both TST and HST of these sequences are recognizable. For pursuing TST of Sq1, drilling depth of the oil-well wasn't enough. Sq2 is the thinnest and Sq2 and Sq3 are the thickest of all. HST of Sq3 is dividable to early HST and late HST. Characteristics of all sequences such as thickness, system tract type and its thickness, number of parasequences and parasequence sets and Microfacies type are in Table 2. Whether the four Burdigalian thirdorder cycles Sq1 through Sq4 documented here are due to eustatic or tectonic control is therefore difficult to answer. We rather suspect a global change in Burdigalian rate of sea-level rise to have been the primary control on facies, depositional environments and stratigraphic architecture [6]. Such inference is also supported by the plausible match of the upper Asmari Formation sea level curve in this oilfield with the Erenberg et al. [4] and global sea level curves of Haq et al. [28].

\section{Conclusion}

The Asmari Formation in study oil field is composed of mudstone, wackestone, packstone, grainstones, rudstones and boundstones. These formed in low- to high-energy homoclinal ramp environments in lagoonal, shoal, restricted, open-marine and mid ramp settings along the foreland basin during the collision of Arabian plate and Iranian micro continent. Facies analysis based on dominant carbonate grain-size and the type and proportion of skeletal (molluscs, echinoderms, foraminifera, corals, and corallinacean) and non-skeletal grains (peloids) in the MIS oil field allowed to differentiate 5 facies associations (including 9 microfacies) ranging from back ramp to mid ramp environments. Their vertical distribution pattern suggests a homoclinal ramp preserving four thirdorder depositional sequences (Sq1 - Sq4) that are Burdigalian in age. TST within each Sq (except Sq2) typically shows restricted and shoal facies overlain by mid ramp facies; the latter usually includes the mfs. During HST

Table 2. Changes of Sequence Stratigraphy in Masjed-I-Solyman oil field Well no.186.

\begin{tabular}{ccccccc}
\hline $\begin{array}{c}\text { Sequence } \\
\text { Symbol }\end{array}$ & $\begin{array}{c}\text { Sequence } \\
\text { thickness }\end{array}$ & System tract & $\begin{array}{c}\text { System tract } \\
\text { thickness }\end{array}$ & $\begin{array}{c}\text { Number of } \\
\text { parasequence }\end{array}$ & $\begin{array}{c}\text { Number of } \\
\text { parasequence set }\end{array}$ & Microfacies type \\
\hline $\mathrm{Sq}_{1}$ & $8.84 \mathrm{~m}$ & $\mathrm{HST}$ & $8.84 \mathrm{~m}$ & 5 & 2 & R1-R3-L1-O2 \\
$\mathrm{Sq}_{2}$ & \multirow{2}{*}{$10.97 \mathrm{~m}$} & $\mathrm{TST}$ & $8.74 \mathrm{~m}$ & 3 & 2 & O3-O4-L1 \\
& & $\mathrm{HST}$ & $2.23 \mathrm{~m}$ & 7 & 3 & M1-R1-O1-O3-L1-R3 \\
$\mathrm{Sq}_{3}$ & $56.41 \mathrm{~m}$ & $\mathrm{TST}$ & $10.67 \mathrm{~m}$ & 6 & 3 & M1-R1-O1-L1-R2-R3 \\
& & HST & $45.74 \mathrm{~m}$ & 17 & 7 & R1-O1-O3-L1-R3-O2-R3 \\
$\mathrm{Sq}_{5}$ & $42.37 \mathrm{~m}$ & TST & $26.79 \mathrm{~m}$ & 7 & 3 & M1-O1-L1-R2-O2-O4-R3 \\
\hline
\end{tabular}




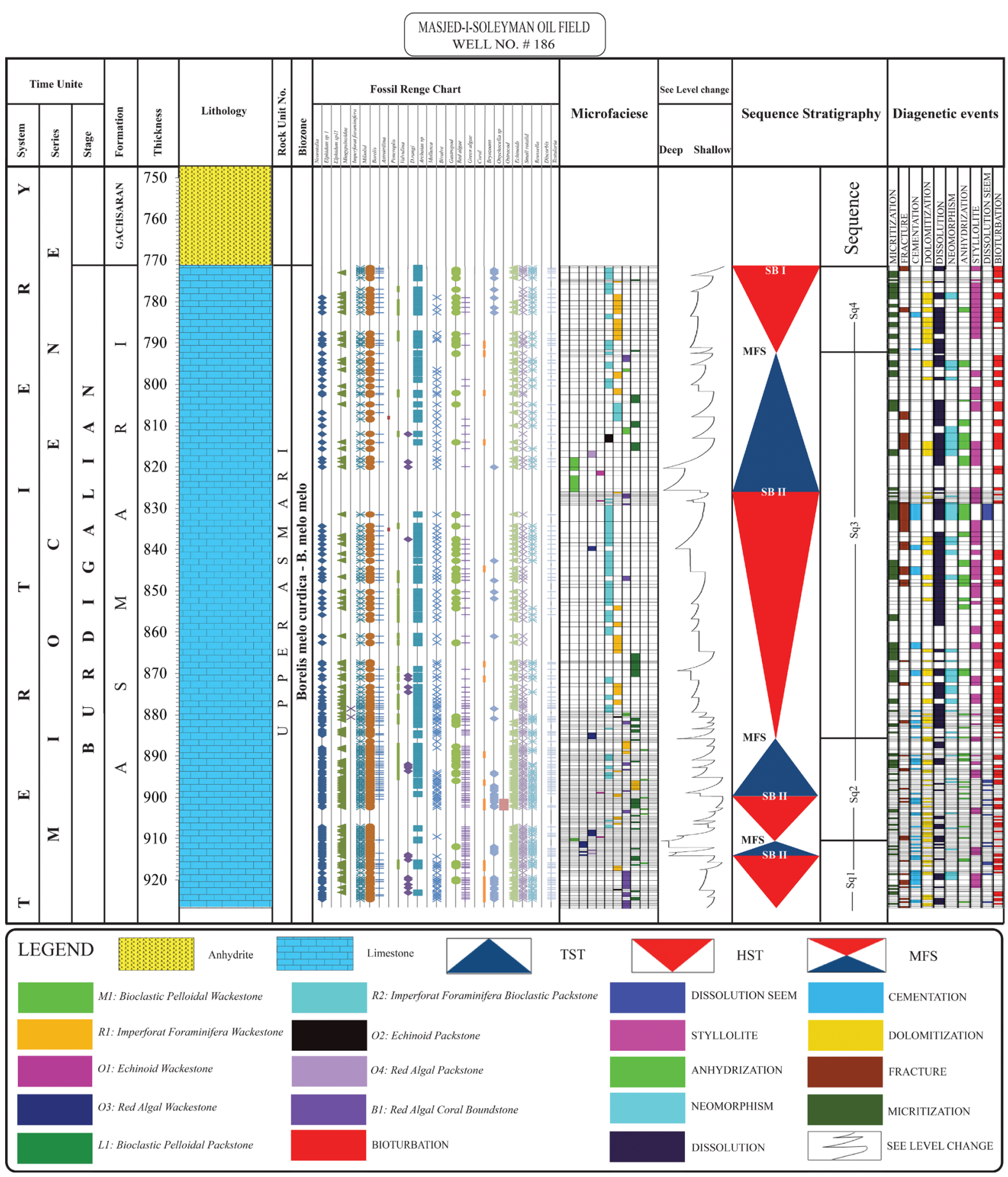

Figure 10. Sequence stratygraphy, relative change of sea level, microfacieses, biostratigraphy, lithostratygraphy and biozonation in Asmari formation in well No. 186, Masjed-I-Soleymanregion oilfield, Iran.

stages, open and mid ramp facies were gradationally overlain by lagoonal facies in shallowing-upward trends. Global eustatic change likely was essential cause of relative sea-level changes of Asmari basin.

\section{References}

[1] Ahmadhadi, F., Lacombe, O. and Marc Daniel, J. (2007) Early Reactivation of Basement Faults in Central Zagros (SW Iran), Evidence from Pre-Folding Fracture Populations in Asmari Formation and Lower Tertiary Paleogeography. In: 
Lacombe, O., Lave, J., Roure, F.,Verges, J., Eds., Thrust Belts and Foreland Basins, Springer, Berlin, 205-228. http://dx.doi.org/10.1007/978-3-540-69426-7_11

[2] Alavi, M. (2004) Regional Stratigraphy of the Zagros Fold-Thrust Belt of Iran and Its Proforeland Evolution. American Journal of Science, 304, 1-20. http://dx.doi.org/10.2475/ajs.304.1.1

[3] Motiei, H. (1993). Stratigraphy of Zagros. Geological Survey of Iran, 536 p. (In Persian)

[4] Ehrenberg, S.N., Pickard, N.A.H., Laursen, G.V., Monibi, S. and Mossadegh, Z.K. (2007) Strontium Isotope Stratigraphy of the Asmari Formation (Oligocene-Lower Miocene), SW Iran. Journal of Petroleum Geology, 30, 102-128. http://dx.doi.org/10.1111/j.1747-5457.2007.00107.x

[5] Van Buchem, F.S.P., Allan, T.L., Laursen, G.V., Lotfpour, M., Moallemi, A., Monibi, S., Motiei, H., Pickard, N.A.H., Tahmasbi, A.R., Vedrenne, V. and Vincent, B. (2010) Regional Stratigraphic Architecture and Reservoir Types of the Oligo-Miocene Deposits in the Dezful Embayment (Asmari and Pabdeh Formations) SW Iran. Geological Society, Special Publications, London, 329, 219-263. http://dx.doi.org/10.1144/SP329.10

[6] Sadeghi, R., Vaziri-Moghaddam, H. and Taheri, A. (2010) Microfacies and Sedimentary Environment of the Oligocene Sequence (Asmari Formation) in Fars Sub-Basin, Zagros Mountains, Southwest Iran. Facies, 57, 431-446. http://dx.doi.org/10.1007/s10347-010-0245-x

[7] Sooltanian, N., Seyrafian, A. and Vaziri-Moghaddam, H. (2011) Biostratigraphy and Paleo-Ecological Implications in Microfacies of the Asmari Formation (Oligocene), Naura Anticline (Interior Fars of the Zagros Basin), Iran. Carbonates Evaporites, 26, 167-180. http://dx.doi.org/10.1007/s13146-011-0053-6

[8] Seyrafian, A., Vaziri-Moghaddam, H., Arzani, N. and Taheri, A. (2011) Facies Analysis of the Asmari Formation in Central and North-Central Zagros Basin, Southwest Iran: Biostratigraphy, Paleoecology and Diagenesis. Revista Mexicana de Ciencias Geológicas, 28, 439-458.

[9] Amirshahkarami, M. (2013) Microfacies Correlation Analysis of the Oligocene-Miocene Asmari Formation, in the Central Part of the Rag-e-Safid Anticlinal Oil Field, Zagros Basin, South-West Iran. Turkish Journal of Earth Sciences, 22, 204-219.

[10] Kangazian, A. and Pasandideh, M. (2016) Sedimentary Environment and Sequence Stratigraphy of the Asmari Formation at Khaviz Anticline, Zagros Mountains, Southwest Iran. Open Journal of Geology, 6, 87-102. http://dx.doi.org/10.4236/ojg.2016.62009

[11] Mahouri, S. (2007) Geochemical Investigation of Cap Rock and Eventual Source Rock’s in Different Horizons of Masjed-I-Solyman Oil Field and Their Role in H2S Generation. Ferdovsy University, 117 p.

[12] Flügel. E. (1982) Microfacies Analysis of Limestone. Springer-Verlag, New York, 633. http://dx.doi.org/10.1007/978-3-642-68423-4

[13] Flügel. E. (2010) Microfacies of Carbonate Rocks Analysis, Interpretation and Application. Springer-Verlag, New York, 976.

[14] Scholle, P.A. and Olmer-Scholle, D.S. (2003) A Color Guide to the Petrogra phy of Carbonate Rock. The American Association of Petrolum Geology, Tulsa, 450 p.

[15] Dunham, R.J. (1962) Classification of Carbonate Rocks According to Depositional Texture. In: Ham, W., Ed., Classification of Carbonate Rocks, a Symposium AAPG, Mem. I, 108-121.

[16] Folk. R.L. (1980) Petrology of Sedimentary Rocks. Hemphills Book Store, Austin.

[17] Wright, V.P. (1992) A Revised Classification of Limestone. Journal of Sedimentary Geology, 76, 177-185. http://dx.doi.org/10.1016/0037-0738(92)90082-3

[18] Wilson. J.L. (1975) Carbonate Facies in Geologic History. Springer-Verlag, New York, 471. http://dx.doi.org/10.1007/978-1-4612-6383-8

[19] Selley, R.E. (2000) Applied Sedimentology. Academic Press, Cambridge, 523.

[20] Catuneanu, O. (2006) Principles of Sequence Stratigraphy. Elsevier, New York.

[21] Catuneanu, O., Galloway, W.E., Kendall, C.G., Miall, A.D., Posamentier, H.W., Strasser, A. and Tucker, M.E. (2011) Sequence Stratigraphy: Methodology and Nomenclature. News of Stratigraphy, 44, 173-245. http://dx.doi.org/10.1127/0078-0421/2011/0011

[22] Laursen, G.V., Monibi, S., Allan, T.L., Pickard, N.A.H., Hosseiney, A., Vincent, B., Hamon, Y., Van Buchem, F.S.H., Moallemi, A. and Driullion, G. (2009) The Asmari Formation Revisited: Changed Stratigraphic Allocation and New Biozonation. 1st International Petroleum Conference \& Exhibition, Shiraz, 1-5. http://dx.doi.org/10.3997/2214-4609.20145919

[23] Vaziri-Moghaddam, H., Seyrafian, A., Taheri, A. and Motiei, H. (2010) Oligocene-Miocene Ramp System (Asmari Formation) in the NW of the Zagros Basin, Iran: Microfacies, Paleoenvironment and Depositional Sequence. Revista Mexicana de Ciencias Geológicas, 27, 56-71. 
[24] Tucker, M.E. and Wright V.P. (1990) Carbonate Sedimentlogy. Blackwell Scientific Publications, Oxford, 482. http://dx.doi.org/10.1002/9781444314175

[25] Geel, T. (2000) Recognition of Stratigraphic Sequence in Carbonat Platform and Slop: Empirical Models Based on Microfacies Analysis of Paloogene Deposits in Southestern Spain. Palaeogeography Palaeoclimatology Palaeoecology, 155, 211-238. http://dx.doi.org/10.1016/S0031-0182(99)00117-0

[26] Pomar, L. (2001) Ecological Control of Sedimentary Accommodation: Evolution from a Carbonate Ramp to Rimmed Shelf, Upper Miocene, Balearic Islands. Journal of Palaeogeology, Palaeoclimatology, Palaeoecology, 175, 249-272. http://dx.doi.org/10.1016/S0031-0182(01)00375-3

[27] Mount, J. (1985) Mixed Siliciclastic and Carbonate Sediments: A Proposed First-Order Textural Compositional Classification. Sedimentology, 32, 435-442. http://dx.doi.org/10.1111/j.1365-3091.1985.tb00522.x

[28] Haq, B.U., Hrdenbol, J. and Vial, P.R. (1987) Chronology of Fluctuating Sea Level. Science, 235, 1156-1167. http://dx.doi.org/10.1126/science.235.4793.1156

\section{Submit or recommend next manuscript to SCIRP and we will provide best service for you:}

Accepting pre-submission inquiries through Email, Facebook, LinkedIn, Twitter, etc.

A wide selection of journals (inclusive of 9 subjects, more than 200 journals)

Providing 24-hour high-quality service

User-friendly online submission system

Fair and swift peer-review system

Efficient typesetting and proofreading procedure

Display of the result of downloads and visits, as well as the number of cited articles

Maximum dissemination of your research work

Submit your manuscript at: http://papersubmission.scirp.org/ 